\title{
DEVELOPMENT OF EFL TEACHERS' PEDAGOGICAL CONTENT KNOWLEDGE THROUGH ACTION RESEARCH IN A MASTER'S PROGRAM
}

\author{
Julio Cesar Gomez \\ Externado University of Colombia, Colombia \\ E-mail: julio.gomez@uexternado.edu.co
}

\begin{abstract}
This longitudinal, 2-year study explored the experience of a cohort of seven in-service teachers in an English Language Teaching master's program as they carried out action research studies to determine the impact of the stages of the research process on the various components of their pedagogical content knowledge. The research design followed a qualitative multiple case study model. Data were gathered through semi-structured interviews, written reflections, and participant observation journal notes. Main findings highlight the way specific components of the thesis linked to stages of the action research study contributed to developing certain types of knowledge integral to pedagogical content knowledge. Knowledge of the students was highly impacted by the needs analysis and the design and implementation of the intervention. In terms of pedagogical knowledge, building the state of the art and theoretical framework along with the intervention clarified and further developed knowledge of teaching methodologies and strategies. Subject matter knowledge was highly impacted by the theoretical framework and the socialization opportunities. Establishing the setting of the study contributed to further understand the constraints and affordances of their teaching contexts. Overall, this action research study became an insightful experience that helped participants promote effective classroom practices to address their students' needs.
\end{abstract}

Keywords: action research, longitudinal case study, master's thesis, pedagogical content knowledge, second language teacher education.

\section{Introduction}

Since the 1980s and 1990s the basis of what constitutes a central aspect of teacher knowledge that permeates all subject areas is pedagogical content knowledge (PCK). The types of teacher knowledge that should become the core of the preparation and teaching practices of teachers in various subject areas have received uneven attention. First coined by Shulman (1986), PCK refers to the "amalgam of content and pedagogy that is uniquely the providence of teachers" $(1987$, p. 8$)$ and reflects the most effective ways of making knowledge comprehensible to learners. Teacher education has actively addressed the development of this type of knowledge in prospective teachers through a variety of opportunities that include field experiences, courses, peer coaching, and so forth. However, "PCK development continues beyond initial licensure (or certification) and should be an integral part of in-service professional development" (Cochran et al., 1991, p. 17). Extensive work has been done to explore the characteristics of this type of knowledge for the corresponding subjects to improve the teaching practices of new and practicing teachers. Science and Math have accumulated a remarkable body of work that has strengthened the preparation of professionals in these fields. Two research studies (Depaepe et al., 2013; Schneider \& Plasman, 2011) have highlighted research on PCK in these content 
PROBLEMS

OF EDUCATION IN THE $21^{\text {st }}$ CENTURY Vol. 78 , No. 4, 2020

534

areas. There is less PCK research in English as a Second Language (ESL) and English as a Foreign Language (EFL) (Evens et al., 2016).

In terms of the sources of PCK, Shulman (1987) included "scholarship in the content disciplines...materials and settings of the institutionalized educational process...research on schooling...the wisdom of practice itself" (p. 18). Grossman (1990) identified four main sources to construct pedagogical knowledge: the apprenticeship of observation, subject matter preparation in teacher education programs, methods courses as professional coursework, and teaching experience in the classroom (pp. 10-16). Both scholars have concurred with the role of teacher education, ongoing research, and experience in the classroom. Also considered are professional development opportunities (Abell, 2008). In the field of second language teacher education, Richards (1991) identified four sources of PCK: "expert opinion, task analysis, teacher-perceived needs and current practice or 'tradition"” (p. 77). Bunch (2013) argued that "one source of pedagogical content knowledge is knowledge about the target language, linguistics, second language acquisition, bilingualism, and so on" for language teachers ( $\mathrm{p}$. 307). Bunch underscored some features of L2 content knowledge and pedagogical knowledge. Richards also suggested building PCK into in-service programs by observing and teaching in different contexts, researching and critically reflecting on teaching and learning, and doing project work, in which he places action research studies. These studies create a powerful "link between campus-based program input and the contexts in which teachers work” (p. 96).

Developing PCK is not only for preparing future teachers but should also "assist experienced teachers to develop more reflective practices and thereby promote further development of their PCK" (Fernandez, 2014, p. 97). Master's programs should structure opportunities for in-service teachers to further develop PCK. Action research in teacher education in general and in language teacher education (Burns, 2009) can be a form of professional development (Burns, 2005), and many graduate education programs have adopted it as one of the "requirements for advanced degrees" (Lebak \& Tinsley, 2010).

The current research focused on action research as a source that has not received much attention in the literature. This research explored the experience of a cohort of EFL English teachers in an ELT master's program as they conducted their action research studies to determine how this type of study and its various stages contributed to the development of PCK.

\section{Theoretical Framework}

\section{Pedagogical Content Knowledge}

Pedagogical content knowledge is the specialized knowledge teachers have to "communicate knowledge to others" (Mirel, 2011, p. 11). It blends content knowledge and general pedagogical knowledge to make the subject matter more accessible to students. Shulman (1986) referred to these forms of representation as "the most powerful analogies, illustrations, examples, explanations, and demonstrations - in a word, the ways of representing and formulating the subject that make it comprehensible to others" (p. 9). It also includes an awareness of students' misconceptions and preconceptions about the subject matter that can make learning difficult or easy (Shulman, 1986). Therefore, students' background and skills need to be considered as the teachers structure and deliver engaging and effective instruction that considers "how particular topics, problems, or issues are organized, presented, and adapted to the diverse interests and abilities of learners" (Shulman, 1987, p. 8). One essential component of PCK is "ensuring that teachers have mastered both the content they will teach and the best ways of teaching it" (Mirel, 2011, p. 11).

How PCK stands in relation to other types of teacher knowledge has evolved since Schulman (1986) placed it along with content knowledge and curricular knowledge. In 1987, 
Shulman positioned pedagogical knowledge at the same level with six other types of knowledge: content knowledge; general pedagogical knowledge; curricular knowledge; knowledge of the students; knowledge of the educational context; and knowledge of educational philosophies, goals, and objectives. Grossman (1990) offered a classification of teacher knowledge that only included four types: subject matter knowledge, general pedagogical knowledge, knowledge of the context, and pedagogical content knowledge (p. 5). Regarding the latter, Grossman (1990) outlined what she considered to be its four central components. First, the "knowledge and beliefs about the purposes for teaching a subject at different grade levels" (p. 8). Second, the knowledge that is related to "students' understanding, conceptions, and misconceptions of particular topics in a subject matter" (p. 8). Third, the knowledge of the particularities of the curriculum in terms of topics and materials in the given subject area. Fourth, "the knowledge of instructional strategies and representations for teaching particular topics" (p. 9). This description highlights the complexity of PCK and how this type of knowledge feeds from other types of knowledge such as subject matter knowledge, knowledge of the students, knowledge of the context (curriculum included), and pedagogical knowledge. More recently, in response to the variety of conceptualizations of PCK, Hashweh (2005) offered another conceptualization of the concept that he calls teacher pedagogical constructions, to include the idea of these constructions as private, personal, and topic-specific, built through experience and more importantly in interaction with other categories of knowledge (pp. 277-279).

In language teacher education, L2 teacher education programs need to address the development of PCK to prepare student teachers and in-service teachers to become effective practitioners. Johnson (2009) described the emergent tendency in L2 teacher education "to recognize, document, and make accessible to L2 teachers the pedagogical content knowledge held and used by L2 teachers as they carry out their work in the diverse contexts when they teach" (p. 22). The idea is that these programs also "provide opportunities to develop reflective skills so that [teacher-learners] can understand and improve practice" (Graves, 2009, p. 118). These practices contribute to "changing the nature and content of schools and colleges" (Mirel, 2011, p. 11).

In order to understand ways that $\mathrm{L} 2$ teacher education can integrate the exploration of the various constituents that support the development of PCK, it is relevant to present how second language teacher education has conceptualized teachers' knowledge. Regarding the knowledge base for English teachers, Larsen-Freeman (1990) described this base as consisting of the knowledge of the learners, pedagogy, and learning. Broadening this view, Freeman and Johnson (1998) argued for a knowledge-base that considers "the activity of language teaching and learning; the school and classroom contexts in which it is practiced; and the experience, knowledge, and beliefs of the teacher as a participant" (p. 413). This conceptualization adds the component of teachers evolving in their interaction with their students and everything that surrounds their teaching. Richards (2017) designated the three main aspects of teachers' knowledge as content knowledge, pedagogical knowledge, and ability and discourse skills. Regarding content knowledge, he included not only aspects related to disciplinary knowledge in fields such as second language acquisition and linguistics but also the language-related knowledge of grammar or phonology, for example. In pedagogical knowledge and ability as related to a teachers' knowledge of teaching, he included the concept of PCK as linked to the ability to make knowledge comprehensible to learners. Discourse skills deal with "the ability to maintain communication in English that is fluent, accurate and comprehensible and more importantly, the extent to which the teacher can use English as a medium to teach English" (p. 14). Teachers' knowledge directly deals with the language proficiency of language teachers to be able to teach English through English.

This research takes as a point of reference the idea of PCK as a separate domain of the knowledge of teaching proposed by Magnusson et al. (1999), but at the same time it "represents 
PROBLEMS

OF EDUCATION IN THE $21^{\text {st }}$ CENTURY Vol. 78 , No. 4, 2020

536

an integrated knowledge system" (p. 117) that is impacted by its constituent parts: subject matter knowledge, pedagogical knowledge, and knowledge of the context. Abell (2008) argued for the need to "employ the components of PCK in an integrated fashion as [teachers] plan and carry out instruction" (p. 1407). Similarly, Gess-Newsome (1999) affirmed that "the task of the teacher is to selectively draw upon the independent knowledge bases of subject matter, pedagogy, and context and integrate them as needed to create effective learning opportunities" (p. 11). Van Driel and Berry (2010) affirmed that "the development of PCK is perhaps best viewed as a complex interplay between knowledge of subject matter, teaching and learning, and context, and the way in which teachers combine and use this knowledge to express their expertise" (p. 659). In my conceptualization of PCK, the knowledge of the students is also included as another component equally important to really account for the complexity of factors that are involved in making the knowledge comprehensible to our learners.

Regarding second language teaching and in particular teaching English as a Foreign Language, the constituent parts are defined as follows. Subject matter knowledge or content knowledge involves, according to Pachler et al. (2007), a high level of FL proficiency; good knowledge and use of the FL structures; and cultural awareness of L2 contexts, linguistic theory, and Fl standards. Similarly, Richards (2017) considered the disciplinary knowledge of English that includes knowledge in areas such as linguistics, sociolinguistics, discourse analysis, and second language acquisition. English as the "language in the classroom plays two roles simultaneously ... as the lesson content and as the means of teaching that content" (Freeman, 2016, p. 178), which is a distinctive feature of second language teaching over other subjects. Pedagogical knowledge considers the strategies and methodologies used for instruction to develop L2 proficiency. Knowledge of the context deals with characteristics of the teaching context including the English language program and curriculum. The knowledge of the students includes "their abilities and learning strategies, ages and developmental levels, attitudes, motivations, and their prior knowledge of the concepts to be taught" (Cochran et al., 1991), plus an understanding of what students know about English, think about English, and how they learn English.

\section{Research on Pedagogical Content Knowledge and Action Research}

One of the first scholars to address the development of PCK in language education was Grossman (1989), who explored the PCK of six teachers of English as a secondary subject. Subsequent research in the area of PCK that focused on second language teaching can be put into three groups: (a) PCK in teachers of languages other than English, (b) PCK in teachers in ESL contexts, and (c) PCK in teachers in EFL contexts. Studies that have explored the development of PCK in teachers of languages different from English (Meijer et al., 1999, 2002; Watzke, 2007; Hlas \& Hildebrandt, 2010). Regarding English, two main groups stand out. Studies conducted in ESL contexts and in EFL contexts. In ESL contexts, studies have explored the PCK of ESL grammar teachers (Johnston \& Goettsch, 2000), teacher educators teaching SLA courses (Gorsuch \& Beglar, 2004; Liu, 2013), ESL teachers involved in the joint-design of workshops (Yates \& Wigglesworth, 2005), and ESL teachers teaching reading (IrvineNiakaris \& Kiely, 2015). In EFL contexts, some studies have explored the characteristics of teachers' PCK in Indonesia (Faisal, 2015; Kultsum, 2017; Setiadi \& Musthafa, 2013; Tosriadi et al., 2018). In Turkey, Atay et al. (2010) examined the process of an experiential task for PCK development of prospective English teachers, whereas Cesur and Ertas (2018) explored the development of PCK of prospective teachers in an ELT department. In China, Hu (2013) explored the characteristics, nature, and sources of secondary teachers' EFL reading PCK. Yang (2011) conducted research in Taiwan to explore how four (two native and two nonnative speakers of English) university English teachers' integrated PCK and educational practice. PCK of 
professors in an undergraduate English program were described by students in Pakistan (Tahir, 2015). The display of PCK of four English teachers was also the focus of research in Indonesia (Ibrahim, 2016). Al-Jaro et al. (2017) explored PCK in the curriculum of an English teacher education program in Yemen. A recent review by Evens et al. (2016) of research literature in L2 and FL and PCK identified a variety of conceptualizations and components of PCK in the 17 studies it reviewed. Two main research lines were identified in these studies: one focusing on the nature of PCK, and the other focusing on the description of teachers' PCK. Some of the studies in their report are included in this review.

Research exploring PCK development through action research is scarce. The four research studies that have included action research examined PCK development in science education. The first two were carried out in the Netherlands. Justi and Van Driel (2005b) conducted research with a group of five science teacher students in a postgraduate training program in which they participated in the models and modelling course combined with a research project carried out in their own classrooms to identify these teachers' development of PCK, content knowledge, and curricular knowledge. The course was structured around specific features of these three types of knowledge that the researchers considered relevant to teaching models and modelling. The research project had these students implement a feature of models and modelling and reflect on its impact on their students. The findings of this research point out the importance of the discussion of new elements and approaches in course activities and the reflection of the results of the research projects they conducted and how they contributed to the development of these teachers' knowledge. Justi and Van Driel (2005a) focused on one beginning chemistry teacher from the same group of students as the previous research and explored how she developed these types of knowledge. The action research study that this student carried out, the discussions in meetings, and the reflections on these experiences contributed to the PCK of her students' ideas about models and modeling. The research project and action research study described in this research consider some aspects characteristic of action research but more a practical implementation of something these students had learned to do. The third research was conducted in Malaysia at the undergraduate level by Halim et al. (2010) and explored the effect of the collaborative action research study conducted by a science student teacher in her practicum and a supervisor on their professional knowledge. The effect of the action research study on the student teacher's PCK consisted of using analogies and simulation as a way to teach effectively. The student also developed a deeper understanding of subject knowledge and research skills. The fourth research (Halai \& Khan, 2011) took place in Pakistan and also focused on the experience of a student in a Master of education program and his supervisor as the former conducted an action research study. The exploration of heat and temperature provided opportunities for the student to develop PCK by adapting subject knowledge using an instructional strategy to teach a given topic, hands-on activities to manipulate abstract concepts, adjusting effective instruction to assessment requirements, and managing resources to use more student-centered methodologies. This research explored the way action research contributes to the development of specific features of PCK in subject areas.

Action research has also been the focus of master's programs: how they structure and support the development of action research (Spencer \& Molina, 2018), the impact on coordinators and teacher researchers (Megowan-Romanowicz, 2010), and assessment of action research projects (McMahon \& Jefford, 2009). A subset of studies explored the experience of master's students conducting action research that addressed teachers' professional development in areas related to the transformation of practices (Bradley-Levine et al., 2009; Lebak \& Tinsley, 2010; Rogers et al., 2007), the impact on current and future practices (O'Connor et al., 2006), the benefits of action research and its impact on teachers' practices (Segal, 2009), and the impact of conducting action research in a master's program on later practices (Barnes, 2013; Meiners, 2016; Shosh \& McAteer, 2016). Although these studies are not directly addressing PCK, they 
Julio Cesar GOMEZ. Development of EFL teachers' pedagogical content knowledge through action research in a master's program

PROBLEMS

OF EDUCATION

IN THE $21^{\text {st }}$ CENTURY

Vol. 78 , No. 4, 2020

538

reflect some of its features implicitly and will be considered in the discussion regarding the findings of the current research.

\section{Research Questions}

1. How do the different components of the action research study conducted in the master's program provide opportunities to develop each one of the components of pedagogical content knowledge?

2. How does the action research study in the ELT master's thesis contribute to the development of pedagogical content knowledge in a group of EFL in-service teachers?

\section{Research Methodology}

\section{Research Type}

A qualitative multiple case study design was adopted for the current research, a type of methodology that predominates in literature to address the exploration of the complex nature of PCK (Hu, 2013, p. 101). Case studies allow the researcher to "investigate real-life events in their natural settings. The goal is to practice sound research while capturing both a phenomenon (the real-life event) and its context (the natural setting)" (Yin, 2004, p. xii). In the current research every in-service teacher became a case, and his or her experience in this master's program while conducting action research studies over a period of two years became the focus of attention to determine its impact on the development of PCK.

\section{Participants}

The seven participants (six females, one male) were EFL in-service teachers in a cohort in a master's program in education with an emphasis in English didactics at the Externado University of Colombia. They participated in the study during the four semesters of their master's program. They worked in public and private schools at different levels of schooling. The topics explored in their action research studies included the enhancement of reading comprehension, speaking fluency, and listening comprehension. Table 1 presents a more detailed description of each participant under a pseudonym of their choice.

Table 1

Participant context, grade level, and teaching experience

\begin{tabular}{llll}
\hline Participant & Context & Grade Level & Years of Experience \\
\hline Laura & Private & 4 & 18 \\
\hline Viviana & Public & 7 & 7 \\
\hline Adela & Private & 8 & 17 \\
\hline Alejandra & Public & 10 & 4 \\
\hline Paula & Private & Undergraduate & 7 \\
\hline Julian & Private & Undergraduate & 7 \\
\hline Lucy & Private & Undergraduate & 9 \\
\hline
\end{tabular}


Three instruments were used to gather data for this research: Semi-structured indepth interviews, written reflections, and participant observation. The written reflections happened in different moments during the 2 years and then after the thesis was completed. The comprehensive final written reflections became the main source of information included here. By the end of the research, the researcher conducted semi-structured in-depth interviews with each participant following an interview schedule focused on identifying the way each stage of the studies they conducted contributed to the development of PCK. The researcher kept a journal to record notes of participant observations as their thesis supervisor throughout the 2 years. The first two instruments became the main source of evidence presented here, although the journal notes were included when relevant. These journal notes were taken after the tutorial sessions throughout the two-year program and focused on the five types of knowledge as they unveiled in the participants' work on their research studies. The idea that its constituent components contribute to building PCK is also reflected in the design of the instruments, which focused on identifying how the different stages of the action research study structured in the thesis contributed to the development of five constituent types of knowledge: subject matter knowledge, pedagogical knowledge, knowledge of the students, knowledge of the context, and knowledge of the curriculum.

\section{Data Analysis}

The researcher analyzed the data from the transcription of the semi-structured indepth interviews, the written reflections, and the journal notes, keeping in mind the categories of knowledge as they related to the different phases of action research as structured in the development of each component of the master's thesis. Coding of the data from each instrument used the substantive coding procedure, in which the "researcher works with the data directly, fracturing and analyzing it, initially through open coding for the emergence of a core category and related concepts and then subsequently through theoretical sampling and selective coding of data" (Holton, 2007, p. 265). This process preceded constant comparison of incidents to achieve theoretical saturation (Holton, 2007).

\section{Research Context: The Master's Program}

The ELT master's program integrated action research into the framework of each of the components of the students' thesis. The first semester, students conducted the needs analysis to identify their research concern and build their state-of-the-art and theoretical framework. The second semester, they defined the research design and instructional design of their pedagogical intervention. The third semester they designed and implemented the materials that became the core of their interventions. The fourth semester students analyzed the data and drew their conclusions. The same tutor supervised the students in each cohort throughout their programs, as they completed each of the stages of the research process and wrote the corresponding thesis chapters. Table 2 presents the structure of the phases of the action research study that related to the different components of the master's thesis: 
Julio Cesar GOMEZ. Development of EFL teachers' pedagogical content knowledge through action research in a master's program

PROBLEMS

OF EDUCATION

IN THE $21^{\text {st }}$ CENTURY

Vol. 78 , No. 4, 2020

540

Table 2

Action research phases as structured in the master's thesis

\begin{tabular}{|c|c|c|}
\hline $\begin{array}{l}\text { Action Research Phases } \\
\text { (Kemmis \& McTaggart, 1988) }\end{array}$ & $\begin{array}{l}\text { Proposed Action Research } \\
\text { Phases }\end{array}$ & Thesis Components \\
\hline \multirow[b]{3}{*}{ Plan } & Identification & Needs analysis \\
\hline & & $\begin{array}{l}\text { Statement of the research problem } \\
\text { Define the research question and objectives } \\
\text { Building the state of the art } \\
\text { Building the theoretical framework } \\
\text { Define research methodology }\end{array}$ \\
\hline & Plan & $\begin{array}{l}\text { Design the pedagogical intervention } \\
\text { - Select the SLA principles } \\
\text { - Identify the theory of nature } \\
\text { of language and language learning } \\
\text { - Define the methodological } \\
\text { approach } \\
\text { - Create the materials } \\
\text { - Pilot the materials }\end{array}$ \\
\hline Action & Action & The pedagogical intervention implementation \\
\hline Observation & Observation & Data gathering with instruments \\
\hline \multirow{2}{*}{ Reflection } & Analysis & Data analysis \\
\hline & $\begin{array}{l}\text { Evaluation and } \\
\text { reflection }\end{array}$ & $\begin{array}{l}\text { Drawing the conclusions and pedagogical } \\
\text { implications }\end{array}$ \\
\hline
\end{tabular}

\section{Research Results}

\section{Knowledge of the Students: Learning About and Connecting with Students through Exploration, Design, and Observation}

During the process of developing the action research study there were four main moments when teachers further expanded on their knowledge of their students. The first was during the needs analysis, when teachers explored what students thought and knew about English and how they learned it. Most teachers acknowledged how this stage in the process contributed to getting to know their students better, because they had to consider their students' backgrounds, views, and needs.

The first part of the process was the needs analysis, and it is what brought me to find this idea about my students. I conducted a survey and informal interview, the way they perceive English, the type of exercises, what comprehension means to them, previous learning experiences with English in their lives. (Interview, Julian)

The needs analysis also allowed teachers to identify students' weaknesses, preferences, and understanding about learning English. Teachers brought up how important this needs analysis was to connecting with their students and realizing some strategies that students found useful. Overall, these teachers found that the needs analysis provided a more realistic picture of 
their current students, and they carried out an informed assessment to identify any problematic Vol. 78 , No. 4, 2020 situations they might tackle in their action research studies.

The second moment when the teachers expanded their knowledge of students involved activities related to the conceptualization of the action research study and the design of the intervention. First was the definition of the research concern, and they had to reflect on what their students really needed and the appropriate methodologies.

For example, in every lesson I am going to explain the vocabulary so they can use it, then I am going to teach them some expressions to give opinions so that they participate confidently in the group discussions. Like doing everything that I could to make my students feel better when they were participating in the group discussions. (Interview, Lucy)

Building the state of the art and the theoretical framework played a more informative role. The former confronted teachers with the bulk of studies related to their topics and populations and presented the intricacies posed by the participants and their contexts. This helped them to realize what their learners could face and realistically achieve in their studies. The theoretical framework helped them comprehend the complexities of language learning as well as the challenges facing their students while learning and developing skills in the target language. The design of the intervention required careful consideration of students to define the second language acquisition principles that were relevant to them, as well as the integration of the principles of the methodological approach selected in the actual design of the materials for the intervention and their piloting.

The third moment of the action research study was during the implementation of the intervention when students experienced the materials created for them. Teachers faced actual instances of language learning and the challenges and affordances provided by the intervention they developed. Teachers acknowledged how the new approach or strategy in the intervention led to positive outcomes in performance:

The careful selection of topics, activities, principles, approach, images and texts had a great impact on students' learning processes. The progress of each student's reading comprehension, motivation, interest, use of the reading strategies increased throughout the implementation. (Written reflections, Paula)

Similarly, these participants highlighted how during the implementation they had to address effectively issues that learners faced in the process. Some of these teachers became aware of the students' potential to learn and change their attitudes toward the work in their English classes to really give it a try.

One last moment was the analysis of the results of the intervention, when teachers tried to understand the impact of their intervention and how that translated into implications for students' learning and their teaching practices. Some teachers realized the complexity of factors that impacted their students' experience, and how they related to the learning experience of their students.

I learnt that every single word, behavior or reaction from the students can give you useful information and so, none of them can be ignored. Everything has a new meaning here since I finally was able to fully understand the reasons regarding my students' behaviors and difficulties. Here I was able to be more empathetic with them. (Written reflections, Adela)

Several teachers expressed and expanded understanding of their students' learning process. One last outcome of this stage was teachers' realization of some changes in their students as a result of the implementation that included improvement in performance and participation in later English courses and the embracement of the work with learning strategies. 
PROBLEMS

OF EDUCATION

IN THE $21^{\text {st }}$ CENTURY

Vol. 78 , No. 4, 2020

542

\section{Pedagogical Knowledge: Reframing Knowledge and Implementing Teaching Methodologies and Strategies for Effective Instruction}

During the development of the action research study, several stages contributed to enriching and expanding in-service teachers' pedagogical knowledge. The needs analysis provided teachers with an opportunity to reflect on their pedagogical practices and those of other teachers as they observed and learned about students' needs and interests in their English classes. Stages such as building the state of the art exposed teachers to research in their field related to their research studies and populations that highlighted novel methodologies and strategies. This triggered their interest in learning more to identify new ways to address instruction for the intervention they needed to create for the action research study.

By reading and looking for related studies, I was able to learn about teaching methodologies and how they work in a classroom, advantages and disadvantages, references, findings and conclusions. (Written reflections, Paula)

The next stage, the building of the theoretical framework, led some teachers to reevaluate the teaching methodologies and strategies they used in class and learn more about new ones to implement in their studies. Some pointed out that there was much they did not know about the ways to address instruction to help their students develop certain language skills.

Building the theoretical framework was the best moment to get informed about teaching methodologies. It implies strategies development and the evolution of the concepts throughout time. In addition, it is an important moment to clarify ideas and stick to one teaching methodology. (Written reflections, Viviana)

Through building theoretical frameworks, teachers had a clear understanding and a sense of ownership of the new methodologies they decided to research and use in their interventions. A couple of teachers pointed out the relevance of this stage in the field by broadening the scope of influence of theory in their teaching practice.

Therefore, reviewing the literature on reading helped me to consider some aspects that most of the cases teachers forget to include when developing reading activities, for example, issues regarding vocabulary, warming up activities and techniques to engage students in reading inside the classroom. (Written reflections, Alejandra)

Intervention design engaged these teachers in the purposeful integration of the new methodologies and strategies they had selected for their intervention. Some teachers were moving away from theory and more toward the practical application of that theory in their materials as a way to structure their teaching during the intervention. In the last stage of the action research process, the implementation of the intervention and the analysis of the results provided a space for teachers to evaluate the effectiveness of the new methodologies and strategies as well as the further impact on their instruction. During the implementation, some teachers realized how some strategies and principles of the new methodologies worked out for students, and the analysis of the results also provided opportunities to see how their teaching practices were altered by their own experience. 
Subject Matter Knowledge: Developing Expertise in L2 Learning and Teaching IN THE $21^{\text {st }}$ CENTURY and Proficiency in English

The action research study conducted by these in-service teachers contributed to the development of features of their content knowledge. Several stages helped some of these teachers clarify concepts about language skills development and second language learning closely linked to their research inquiries. Building the state of the art and the theoretical framework informed teachers about nuances of the development of language skills such as reading, listening, and speaking, and even revisited features of second language learning and teaching.

The literature review about reading and strategies allowed me first to understand the importance of the reading processes in both decoding and comprehension stages. (Written reflections, Alejandra)

In the theoretical framework, because I did not have any idea about the listening process so when you started to know that in their minds they had to relate the meaning, they have to understand everything at once. (Interview, Adela)

Regarding the teachers' development of features of language proficiency in English, there were mainly two aspects related to the process of thesis socialization that stood out as contributors. One aspect that contributed to the development of writing enhancement was the writing of the document itself, particularly the theoretical framework and the data analysis.

Working on a study, and writing the thesis I learned a lot, I broadened my vocabulary, reading, writing, and speaking, and in general improved this and people told me that now. (Interview, Laura)

The design of the intervention in the form of the materials created and piloted provided opportunities to review teachers' issues with language.

During the design of the worksheets, I realized that some of my students still had some problems with grammar and vocabulary that I had to point out to them. These problems reduced as the students moved through the design of the materials, and in the final worksheets there were no problems. Proofreading both the drafts of their thesis documents and their materials was something I had to encourage repeatedly. (Journal note, third semester)

Also related to the thesis process were opportunities to socialize advances of the action research process and how they contributed to changes in the way their classes were conducted in the target language. In particular, some teachers acknowledged the way their speaking improved as a result of their interaction with the discussion of their action research studies with classmates and supervisor.

I feel more confident to speak. Because of the classes and the work on the thesis, reading, investigating, of course my level of English improved a lot. I try all the class in English with my fourth graders and they understand my explanations, my examples, my instructions and they understand me. (Interview, Laura)

\section{Knowledge of the Curriculum: Navigating the Challenges}

There were certain instances when these teachers were confronted with challenges posed by the institution's curriculum as they defined, implemented, and analyzed the results of their action research studies. During the needs analysis, some teachers felt the need to involve their 
PROBLEMS

OF EDUCATION

IN THE $21^{\text {st }}$ CENTURY

Vol. 78, No. 4,2020

544

learners in the selection of the topics to be explored in their interventions as a way to engage and make this feature of their classes more relevant to them.

When we consider students' opinions, maybe we can get closer to that process of language acquisition, and we force ourselves to go beyond those topics that we really enjoy and we really like... and maybe I think when we open our minds to different topics and learn about those topics we can think of other ways of structuring our classes. (Interview, Alejandra)

The description of the setting and the design of the intervention exposed a need to explore in detail the most important characteristics of the institution's curriculum in order to proceed with the inquiry to be addressed by their action research studies.

I knew coherence between the institutional syllabus and action was not present, but I had not identified what were the exact problems. Now that I learnt about it I discovered the importance of coherence in planning and materials as well as their impact on action. (Written reflections, Adela)

It was through the building of the literature review that some teachers realized the potential of creating materials or adapting existing ones to support more effectively the learning process of their students in the action research study. This later materialized through the design and implementation of the materials for the intervention.

I think now I worry more for creating materials that really help the students use the language in a more functional way. (Written reflections, Alejandra)

One last moment when these teachers realized the many incongruences posed by their institution's current curriculum was during data analysis. In this stage they vented their frustration at the restrictions these curricula posed and the value of their research experience with their studies to provide better conditions for learning and teaching in their institutions.

Now I have a deeper idea, now it is easier for me to see that there is a lack of coherence with the things that we say we do and what we actually do as a school. Like saying we are using the communicative approach, but it is actually more grammar like, and we are not giving real opportunities for the students to produce, to really improve like their skills. (Interview, Adela)

\section{Knowledge of the Context: Identifying Opportunities for Learning from the Context}

Three main stages of the action research study contributed to the teachers' knowledge of the context. In the building of the related studies section, teachers understood the scope of their action research studies within the field's literature, and this helped them to gain some perspective. While teachers were establishing the characteristics of their settings, they realized the complexity of the factors they had to consider to address comprehensively the needs of their learners.

Then when I worked on the setting of the study, basically because we had to consider everything, the information about the population, the age of the students, the characteristics of the school, the way the school has been teaching, so that's a good way to know what has been happening with the same group of students, so that was good. (Interview, Viviana)

One last stage that contributed to their knowledge of the context was the design of their intervention. At this point they had to consider the guidelines of their language programs when designing their interventions. 
For this identification it was necessary to know how the idea of teaching at school was. I can affirm it was a good chance to have more information about the way teaching language is understood in my context. (Written reflections, Viviana)

\section{Embracing the Potential of Action Research to Tailor Instruction to Meet Learners 'Needs, Interests, and Styles}

Considering the action research study that these teachers conducted as a whole, it is possible to assert the positive impact it had on their pedagogical content knowledge understood as the ability to structure instruction to better address the way students learn and achieve their potential as second language learners.

I think I am crazy about that because all the time I am thinking about conducting the needs analysis to see the topics, to get my students to participate in the process of constructing the curriculum we are going to follow. (Interview, Alejandra)

Well, you get sucked in the cycle, you have this cycle, when you analyze and define the problem, and you find ways to tackle the program and then you see the results and you think about it and evaluate it, and then from this evaluation comes the reflection and then you come over again. (Interview, Julian)

We can do it in a small scale; you don't have to have big impact. But maybe you can test something small with your students, and you can see if they are actually learning or not. (Interview, Lucy)

This action research is something that actually I do in my classes every single day, because I find something, a problematic situation, for example, a student who is not really learning, who is behind, then I talk to him, then I design a plan, like do the plan, follow the plan, then reflect and do this cycle in every problematic situation. (Interview, Paula)

Some aspects that stand out in these accounts deal with the ways these teachers see their students and attempt to explore their needs, interests, and backgrounds to tailor the methodologies and strategies to more effectively address issues they may face in the teaching and learning process. Following several stages of the action research cycle made sense to them and turned out to be an effective way to explore their classrooms to identify relevant problems. Building knowledge informed pedagogical choices to implement through structured interventions, which ultimately called for further reflection through observation of the student outcomes.

\section{Discussion}

Several stages of their action research studies highly impacted these in-service teachers' knowledge of their students. In terms of opportunities to learn directly about their students' needs, characteristics, and backgrounds, it was the needs analysis stage that got them to stop, observe, and reflect on their students. Rogers et al. (2007) stated that when in-service teachers in a master's program conduct action research, they "develop a greater mindfulness towards their children" (p. 217), which was reflected in their getting closer to them, better understanding them as learners, and giving them an active role in the class. These were things teachers in the current study experienced in the needs analysis stage at the beginning of the research process. Regarding the impact, implementation of the intervention and the analysis of the results made these teachers notice how the students responded to the materials and to what extent they were learning and how. This finding confirms the results of Justi and Van Driel's (2005b) study that explored teacher's knowledge development through research projects, testing new ideas in the 
PROBLEMS

OF EDUCATION IN THE $21^{\text {st }}$ CENTURY Vol. 78 , No. 4, 2020

546

classroom and analyzing how they contribute or not to students' learning. The experiences of teachers engaged in action research in a master's in math education in Segal's (2009) study also reported becoming more reflective, better observers, and aware of the impact of instruction on their learners. Other stages such as the definition of the research concern and the design of the materials helped teachers keep the focus on their students as they defined the issue to tackle, created the intervention considering an array of principles and tenets, and piloted their materials. Playing a more informative role was the building of the state of the art and the theoretical framework, which contributed to placing their students and the issues they were addressing in their action research studies within the realm of the literature.

Several stages directly impacted pedagogical knowledge. The needs analysis was the initial moment when teachers had to reflect carefully on the teaching methodologies they and their colleagues used and how effective they had been with the population (Bradley-Levine et al., 2009; Halai \& Khan, 2011). The state of the art allowed these teachers to be exposed to other methodologies and strategies that had been used to address similar problematic situations with similar populations to then decide on the more appropriate one, considering the characteristics of their current students.

While building the theoretical framework, these teachers explored and learned about the features and principles of the new and old methodologies they had selected to frame their interventions, putting theory into practice. This is a feature of action research that when enacted leads to changes in real settings (Carr \& Kemmis, 1986). During the design of the intervention, these teachers had to make sure they considered all the principles of the selected methodologies and strategies and sometimes even revisited features of effective lesson structuring.

Finally, the implementation of the materials and the analysis of the results confronted teachers with the outcomes of their application of the methodologies for their students and for themselves, as they would realize ways their teacher practices had been positively enriched by the positive results of their action research studies. Notably, these teachers considered students' feedback during the implementation, which was also reported by the three teachers in Lebak and Tinsley's (2010) study.

The action research studies and the process of writing the thesis impacted two aspects of subject matter knowledge. Building the state of the art and the theoretical framework provided insights into the learning process of language skills development, which closely related to the domain knowledge of language teachers. Similarly, the results of Halai and Khan's (2011) study asserted that as an innovative method of teaching is implemented, it requires more profound knowledge of the content knowledge. In the current case this involved revisiting the understanding of language skills development. Regarding the content that in second language teaching is also the means of instruction, in this case English, some teachers reported that their English language proficiency had improved. Writing the thesis document enhanced their writing and speaking, along with providing other opportunities to socialize their action research process with classmates and supervisor.

Issues related to these teachers' knowledge of the curriculum at the micro and macro levels were considered at several stages of the action research studies. At the micro level, in the needs analysis the topics to be explored in the materials became an issue to be addressed considering learners' interests and specific characteristics of their programs. Similarly, Rogers et al. (2007) argued that teachers who engage in action research tend to "thoughtfully include students in curricular and pedagogical decisions" (p. 221). This was something reflected in teachers' decisions to embrace students' interests when selecting possible topics for the intervention.

At the macro level, the description of the setting made them explore in detail the demands of their curricula for later consideration to align them with the design of the intervention. Through the building of the literature review teachers also realized the benefits of designing their own 
materials according to their students and teaching contexts. Finally, the data analysis revealed Vol. 78 , No. 4, 2020 the challenges that their curricula posed for several teachers and their teaching practices. This validates what Bradley-Levine et al. (2009) found, which that some of the teachers in this study pointed out, regarding enhancing inadequate curricula for students.

Regarding knowledge of the context, certain stages in the action research study afforded opportunities to look into features of their contexts. The state of the art positioned their action research studies within the realm of research and other contexts explored. The description of the setting helped them realize the complexity of factors they needed to consider to effectively address their students and their sociocultural contexts. The design of the intervention also engaged them in careful consideration of the guidelines of their programs and all the resources available to structure their interventions accordingly.

Beyond the empowering role of action research in the classroom and as an appropriate form of professional development (McKay, 1992; McNiff, 2010), this type of research becomes a source for developing PCK for those in-service teachers who carry it out as part of their master's programs, as seen in these teachers' experiences. All participants acknowledged how positive and rewarding the experience of conducting their action research studies was in their classrooms. This validates the positive outcomes for teachers in some studies exploring the impact of action research conducted as part of master's programs (Barnes, 2013; Meiners, 2016; O'Connor et al., 2006; Segal, 2009;).

In-service teachers in the present study felt that they opened up to exploring what their students knew about English, what the students felt about their performance and English learning, and how their own backgrounds impacted what they were or were not doing in class. They began to actively use this information to identify which issue to address in their research and shape the intervention. Getting informed in order to place their study and define the methodology and strategy needed to build their state of the art and methodological approach became an opportunity to learn and sometimes relearn. The creation of the intervention, the careful consideration of its various components, and then observing their students in their interaction with it, highlighted the relevance of finding ways to make the learning experience more student centered and meaningful. Pedagogical content knowledge of these teachers was enriched by the experience of conducting their action research studies, as reflected in the inclusion of some action research features in their practice after finishing their master's programs, and their concern with putting students as the core of their instruction. More importantly, the participants in the current study seemed to echo the findings of Shosh and McAteer's (2016) study, which found that teachers who carried out action in their master's developed "their own processes for reflecting on, interrogating, and changing their practice" (p. 15), one of the outcomes of developing PCK through action research.

\section{Conclusions}

The findings presented here highlight the interrelation of these various types of knowledge and how they all contribute to these in-service teachers' pedagogical content knowledge. The stages of the action research study provided important opportunities to build their knowledge of their students through continuous observation of their performance after a careful initial reencounter with them in the needs analysis stage. Reframing and expanding their understanding of teaching methodologies and strategies through building their state of the art and theoretical framework contributed to enhancing their pedagogical knowledge, as instruction became more focused on providing meaning and supported students' learning experiences.

Regarding their knowledge of their context and curriculum, revisiting their teaching contexts, language programs, and curricula while establishing the setting of their studies confronted these teachers with constraints and opportunities that they had to embrace to 
PROBLEMS

OF EDUCATION IN THE $21^{\text {st }}$ CENTURY Vol. 78 , No. 4, 2020

548

find ways to design and implement their interventions in their studies. Finally, their subject matter knowledge increased through the review of literature on language learning, skill development, and written and oral reports of their research as a way to improve their own L2 proficiency. Overall, PCK for EFL teaching that these in-service teachers developed through their action research studies consisted of the merging of the constituent types of knowledge as they interacted to make teachers aware of students' needs and interests; to define effective pedagogical strategies; to create meaningful interventions in their classroom considering the contextual and curricular characteristics of their teaching context; to place L2 learners at the center of the instruction.

The practical knowledge involved learning about the particularities of the students, their contexts, and the methodologies and strategies most appropriate for them. The formal knowledge included more advanced understanding of the L2 learning and teaching methodologies and strategies that these teachers attained to design and implement their interventions. Therefore, the source for this blend is the action research study, where the informed intervention becomes the opportunity to structure a learning experience for the students.

One of the pedagogical implications of this study is the need to support the preparation of in-service teachers in master's ELT programs or in any other areas to develop well-designed action research studies and take advantage of each stage of the research process to learn and continuously observe our learners, so as to provide them with the most supportive and current teaching practices. A limitation of the current study is the emphasis on materials development to structure the intervention of the action research studies. This emphasis may have prevented the participants from finding their own ways of creating their interventions. Another limitation could be the fact that this researcher was also acting as the thesis supervisor. However, this role allowed the researcher to carefully follow the participants' research experience.

\section{References}

Abell, S.(2008). Twentyyears later: Does pedagogical content knowledgeremainauseful idea? International Journal of Science Education, 30(10), 1405-1416. https://doi.org/10.1080/09500690802187041

Al-Jaro, M., Asmawi, A., \& Hasim, Z. (2017). Content analysis of the pedagogical content knowledge in the curriculum of Yemeni EFL teacher education programme. Arab World English Journal, 8(1), 264-279. http://doi.org/https://dx.doi.org/10.24093/awej/vol8no1.19

Atay, D., Kaslioglu, O., \& Kurt, G. (2010). The pedagogical content knowledge development of prospective teachers through an experiential task. Procedia Social and Behavioral Sciences, 2(2), 1421-1425. https://doi.org/10.1016/j.sbspro.2010.03.212

Barnes, J. S. (2013). Teachers' continuation of action research elements after conducting studies during a master's program [Doctoral dissertation, University of South Dakota]. Proquest Dissertations and Theses Global.

Bradley-Levine, J., Smith, J., \& Carr, K. (2009). The role of action research in empowering teachers to change their practice. Journal of Ethnographic \& Qualitative Research, 3(3), 152-161.

Bunch, G. C. (2013). Pedagogical language knowledge preparing mainstream teachers for English learners in the new standards era. Review of Research in Education, 37(1), 298341. https://doi.org/10.3102\%2F0091732X12461772

Burns, A. (2005). Action research: An evolving paradigm? Language Teaching, 38(2), 57-74. https://doi.org/10.1017/S0261444805002661

Burns, A. (2009). Action research in second language teacher education. In A. Burns \& J. C. Richards (Eds.), The Cambridge guide to second language teacher education (pp. 289-297). Cambridge University Press.

Carr, W., \& Kemmis, S. (1986). Becoming critical: Education, knowledge and action research. Falmer. https://doi.org/10.4324/9780203496626 
Cesur, K., \& Ertas, A. (2018). Examining the prospective English teachers' pedagogical content knowledge: Canakkale case. International Journal of Progressive Education, 14(3), 123139. https://doi.org/10.29329/ijpe.2018.146.9

Cochran, K. F., King, R. A., \& DeRuiter, J. A. (1991). Pedagogical content knowledge: A tentative model for teacher preparation (ED340683). ERIC. https://files.eric.ed.gov/fulltext/ED340683.pdf

Depaepe, F., Verschaffel, L., \& Kelchtermans, G. (2013). Pedagogical content knowledge: A systematic review of the way in which the concept has pervaded mathematics educational research. Teaching and Teacher Education, 34, 12-25. https://doi.org/10.1016/j.tate.2013.03.001

Evens, M., Elen, J., \& Depaepe, F. (2016). Pedagogical content knowledge in the context of Foreign and second language teaching: A review of the research literature. Porta Linguarum, 26, 187-200. http://hdl.handle.net/10481/53944

Faisal. (2015). Pedagogical content knowledge in Indonesian English language teaching. Asia Pacific Journal of Multidisciplinary Research, 3(5), 103-110. http://www.apjmr.com/wp-content/ uploads/2016/01/APJMR-2015-3.5.2.14.pdf

Fernandez, C. (2014). Knowledge base for teaching and pedagogical content knowledge (PCK): Some useful models and implications for teachers' training. Problems of Education in the 21st Century, 60, 79-100. http://www.scientiasocialis.lt/pec/node/906

Freeman, D. (2016). Educating second language teachers. Oxford University Press.

Freeman, D., \& Johnson, K. E. (1998). Reconceptualizing the knowledge-base of language teacher education. TESOL Quarterly, 32(3), 397-417. https://doi.org/10.2307/3588114

Gess-Newsome, J. (1999). Pedagogical content knowledge: An introduction and orientation. In J. GessNewsome \& N. G. Lederman (Eds.), PCK and Science Education (pp. 3-17). Kluwer Academic Publishers. https://doi.org/10.1007/0-306-47217-1_1

Gorsuch, G., \& Belgar, D. (2004). Teaching second language acquisition courses: Views from new faculty. The Electronic Journal for English as a Second Language, 8(1), A-2. http://cwp60.berkeley. edu:16080/tesl-ej/ej29/a2.htm

Graves, K. (2009). The curriculum of second language teacher education. In A. Burns \& J. C. Richards (Eds.), The Cambridge guide to second language teacher education (pp. 115-124). Cambridge University Press.

Grossman, P. L. (1989). A study in contrast: Sources of pedagogical content knowledge for secondary English.Journal of Teacher Education, 40(5),24-31.https://doi.org/10.1177/002248718904000504

Grossman, P. L. (1990). The making of a teacher: Teacher knowledge and teacher education. Teachers College Press.

Halai, N., \& Khan, M. A. (2011). Developing pedagogical content knowledge of science teachers through action research: A case study from Pakistan. Asia-Pacific Forum on Science Learning and Teaching, 12(1), 1-23. http://ecommons.aku.edu/pakistan_ied_pdck/18

Halim, L., Buanga, N. A., \& Meeraha, T. S. (2010). Action research as instructional supervision: Impact on the professional development of university-based supervisors and science student teachers. Procedia-Social and Behavioral Sciences, 2(2), 28682871. https://doi.org/10.1016/j.sbspro.2010.03.430

Hashweh, M. (2005). Teacher pedagogical constructions: A reconfiguration of pedagogical content knowledge. Teachers and Teaching: Theory and Practice, 11(3), 273-292. https://doi.org/10.1080/13450600500105502

Hlas, A., \& Hildebrandt, S. (2010). Demonstrations of pedagogical content knowledge: Spanish Liberal Arts and Spanish Education majors' writing. L2 Journal, 2(1), 1-22. https://doi.org/10.5070/12219059

Holton, J. (2007). The coding process and its challenges. In A. Bryant \& K. Charmaz (Eds.), The SAGE handbook of grounded theory (pp. 265-289). Sage. https://doi.org/10.4135/9781848607941.n13

$\mathrm{Hu}$, J. (2013). Case studies of teachers' pedagogical content knowledge (PCK) for teaching EFL reading [Unpublished doctoral dissertation]. Chinese University of Hong Kong.

Ibrahim, B. (2016). Pedagogical content knowledge for teaching English. English Education Journal, 7(2), 155-167. http://www.jurnal.unsyiah.ac.id/EEJ/article/viewFile/3730/3420

Irvine-Niakaris, C., \& Kiely, R. (2015). Reading comprehension in test preparation classes: An analysis of teachers' pedagogical content knowledge in TESOL. TESOL Quarterly, 49(2), 369-392. https://doi.org/10.1002/tesq.189 
Julio Cesar GOMEZ. Development of EFL teachers' pedagogical content knowledge through action research in a master's program

PROBLEMS

OF EDUCATION

IN THE $21^{\text {st }}$ CENTURY Vol. 78 , No. 4, 2020

550

Johnson, K. E. (2009). Trends in second language teacher education. In A. Burns \& J. C. Richards (Eds.), The Cambridge guide to second language teacher education (pp. 20-29). Cambridge University Press.

Johnston, B., \& Goettsch, K. (2000). In search of the knowledge base of language teaching: Explanations by experienced teachers. The Canadian Modern Language Review, 56(3), 437468. https://doi.org/10.3138/cmlr.56.3.437

Justi, R., \& Van Driel, J. (2005a). A case study of the development of a beginning chemistry teacher's knowledge about models and modelling. Research in Science Education, 35(2-3), 197-219. https://doi.org/10.1007/s11165-004-7583-z

Justi, R., \& Van Driel, J. (2005b). The development of science teachers' knowledge on models and modelling: Promoting, characterizing, and understanding the process. International Journal of Science Education, 27(5), 549-573. https://doi.org/10.1080/0950069042000323773

Kemmis, S., \& McTaggart, R. (Eds.). (1988). The action research planner (3rd. ed.). Deakin University Press.

Kultsum, U. (2017). The concept of pedagogical content knowledge (PCK): Recognizing the English teachers' competences in Indonesia. Advances in Social Science, Education and Humanities Research, 134, 55-59. https://dx.doi.org/10.2991/icirad-17.2017.11

Larsen-Freeman, D. (1990). On the need for a theory of second language teaching. In J. E. Alatis (Ed.), Georgetown University round table on languages and linguistics: Linguistics, language teaching, and language acquisition: The interdependence of theory, practice, and research (pp. 261-270). Georgetown University Press. https://repository.library.georgetown.edu/bitstream/ handle/10822/555483/GURT_1990.pdf

Lebak, K., \& Tinsley, R. (2010). Can inquiry and reflection be contagious? Science teachers, students, and action research. Journal of Science Teacher Education, 21(8), 953-970. https://doi.org/10.1007/s10972-010-9216-x

Liu, S. (2013). Pedagogical content knowledge: A case study of ESL teacher educator. English Language Teaching, 6(7), 128-138. https://doi.org/10.5539/elt.v6n7p128

Magnusson, S., Krajcik, J., \& Borko, H. (1999). Nature, sources and development of pedagogical content knowledge for science teaching. In J. Gess-Newsome \& N. G. Lederman (Eds.), Examining pedagogical content knowledge (pp. 95-132). Kluwer Academic Publishers https://doi.org/10.1007/0-306-47217-1_4

McKay, J. (1992). Professional development through action research. Journal of Staff Development, 13(1), $18-21$.

McMahon, T., \& Jefford, E. (2009). Assessing action-research projects within formal academic programmes: Using Elliott's context-related criteria to resolve the rigour versus flexibility dilemma. Educational Action Research, 17(3), 359-371. https://doi.org/10.1080/09650790903093250

McNiff, J. (2010). Action research for professional development: Concise advice for new action researchers. September Books.

Megowan-Romanowicz, C. (2010). Inside out: Action research from the teacher-researcher perspective. Journal of Science Teacher Education, 21(8), 993-1011. https://doi.org/10.1007/ s10972-010-9214-Z

Meijer, P. C., Verloop, N., \& Beijaard, D. (1999). Exploring language teachers' practical knowledge about teaching reading comprehension. Teaching and Teacher Education, 15(1), 59-84. https://doi.org/10.1016/s0742-051x(98)00045-6

Meijer, P. C., Verloop, N., \& Beijaard, D. (2002). Multi-method triangulation in a qualitative study on teachers' practical knowledge: An attempt to increase internal validity. Quality and Quantity, 36(2), 145-167. https://doi.org/10.1023/a:1014984232147

Meiners, J. D. (2016). A phenomenological study of professional and practical changes experienced by teachers involved with action research in a learning community master's program [Unpublished doctoral dissertation]. Minnesota State University.

Mirel, J. (2011). Bridging the widest street in the world: Reflection on the history of teacher education. American Educator, 35(2), 6-12. https://www.aft.org/sites/default/files/periodicals/Mirel.pdf

O'Connor, K. A., Greene, H. C., \& Anderson, P. J. (2006). Action research: A tool for improving teacher quality and classroom practice (ED494955). ERIC. https://files.eric.ed.gov/fulltext/ED494955. pdf 
Pachler, N., Evans, M., \& Lawes, S. (2007). Modern foreign languages: Teaching school subjects. Routledge. https://doi.org/10.4324/9780203932797

Richards, J. (1991). Content knowledge and instructional practice in second language teacher education. In J. A. Alatis (Ed.), Georgetown University round table on languages and linguistics 1991 (pp.7699). Georgetown University Press.

Richards, J. C. (2017). Teaching English through English: Proficiency, pedagogy and performance. RECL Journal, 48(1), 7-30. https://doi.org/10.1177/0033688217690059

Rogers, D., Bolick, C. M., Anderson, A., Gordon, E., Manfra, M. M., \& Yow, J. (2007). "It's about the Kids": Transforming teacher-student relationships through action research. The Clearing House: A Journal of Educational Strategies, Issues and Ideas, 80(5), 217-222. https://doi.org/10.3200/tchs.80.5.217-222

Schneider, R. M., \& Plasman, K. (2011). Science teacher learning progressions: A review of science teachers' pedagogical content knowledge development. Review of Educational Research, 81(4), 530-565. https://doi.org/10.3102/0034654311423382

Segal, S. U. (2009). Action research in mathematics education: A study of a master's program for teachers [Unpublished doctoral dissertation]. Montana State University.

Setiadi, R., \& Musthafa, B. (2013). Pedagogical content knowledge (PCK) and teaching performance of Indonesia's language teachers at the aftermath of teacher certification program: A case of Indonesia. Asia-Pacific Collaborative Education Journal, 9(2), 69-78. http://apcj.alcob.org/ journal/article.php?code $=21331 \&$ ckattempt $=1$

Shosh, J. M., \& McAteer, M. (2016). The CARN/ARNA inaugural study day inquiry: What happens to action research after the master's degree? Educational Action Research, 24(1), 4-20. https://doi.org/10.1080/09650792.2015.1132001

Shulman, L. S. (1986). Those who understand: Knowledge growth in teaching. Educational Researcher, 15(2), 4-14. https://doi.org/10.3102/0013189x015002004

Shulman, L. S. (1987). Knowledge and teaching: Foundations of the new reform. Harvard Educational Review, 57(1), 1-23. https://doi.org/10.17763/haer.57.1.j463w79r56455411

Spencer, J. A., \& Molina, S. C. (2018). Mentoring graduate students through the action research journey using guiding principles. Educational Action Research, 26(1), 144165. https://doi.org/10.1080/09650792.2017.1284013

Tahir, K. (2015). Professor pedagogical content knowledge, motivation, transformational teaching, and student deep learning in bachelor English programs at Pakistani universities [Unpublished doctoral dissertation]. Dowling College.

Tosriadi, T., Asib, A., Marmanto, S., \& Azizah, U. A. (2018). In-service EFL teachers' reflection as a pathway to develop professionalism. International Online Journal of Education and Teaching, 5(4), 921-932. http://iojet.org/index.php/IOJET/article/view/467/302

Van Driel J., \& Berry, A. (2010) The teacher education knowledge base: Pedagogical content knowledge. In B. McGraw, P. L. Peterson, \& E. Baker (Eds.), International Encyclopedia of Education (pp. 656-661). Elsevier. https://doi.org/10.1016/b978-0-08-044894-7.00642-4

Watzke, J. L. (2007). Foreign language pedagogical knowledge: Toward a developmental theory of beginning teacher practices. The Modern Language Journal, 91(1), 63-82. https://doi.org/10.1111/ j.1540-4781.2007.00510.x

Yang, H. H. (2011). Exploring native and non-native English teachers' integrated pedagogical content knowledge and instructional practice: A case study of four teachers at a Taiwan university [Unpublished doctoral dissertation]. The Ohio State University.

Yates, L., \& Wigglesworth, G. (2005). Researching the effectiveness of professional development in pragmatics. In N. Bartels (Ed.), Applied linguistics and language teacher education (pp. 261280). Springer. https://doi.org/10.1007/1-4020-2954-3_15

Yin, R. (Ed.). (2004). The case study anthology. Sage. 
Julio Cesar GOMEZ. Development of EFL teachers' pedagogical content knowledge through action research in a master's program PROBLEMS OF EDUCATION IN THE $21^{\text {st }}$ CENTURY Vol. 78 , No. 4,2020

Received: May 04, 2020

Accepted: August 02, 2020

Cite as: Gomez, J. C. (2020). Development of EFL teachers' pedagogical content knowledge through action research in a master's program. Problems of Education in the $21^{\text {st }}$ Century, 78(4), 533-552. https://doi.org/10.33225/pec/20.78.533

Julio Cesar Gomez

$\mathrm{PhD}$, Coordinator of Master's in Education Programs, School of Education, Externado University of Colombia, Calle 12 \# 1-17 este, Edificio C, Piso 5, Bogota, Colombia.

E-mail: julio.gomez@uexternado.edu.co

Website: https://www.uexternado.edu.co/ciencias-de-la-educacion/

ORCID: https://orcid.org/0000-0002-0626-0669 